\title{
Teaching NeuroImages: Congenital variant misdiagnosed as cerebral venous sinus thrombosis \\ Clinical pitfall
}

Sara Dawit, MD, Devika M. Das, Marie D. Acierno, MD, and Cumara B. O'Carroll, MPH, MD

Neurology ${ }^{\circledR}$ 2019;92:e2064-e2065. doi:10.1212/WNL.0000000000007372
Correspondence

Dr. O'Carroll

Ocarroll.Cumara@mayo.edu

Figure Various imaging modalities



C

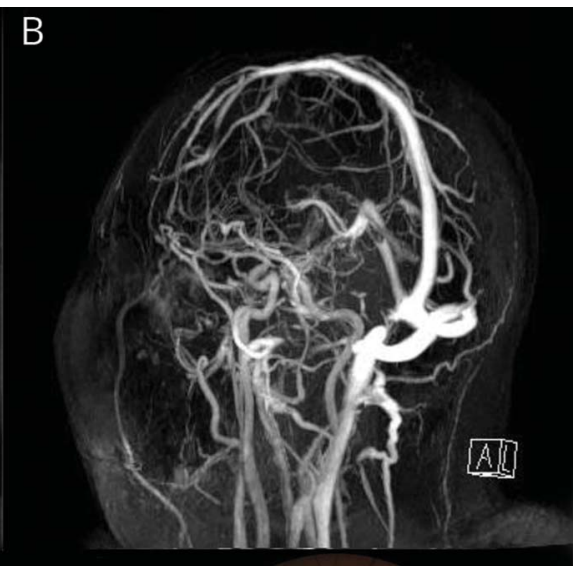

D

(A, B) Magnetic resonance venography demonstrates a hypoplastic medial right transverse sinus and is likely a congenital variant. Lateral to the vein of Labbe the right transverse sinus and sigmoid sinus are small, but patent. Dominant left transverse sinus, superior sagittal sinus, internal cerebral veins, and straight sinus are all unremarkable in appearance. (C) Right fundus photograph demonstrates grade 2 papilledema using Frisen grading scale. (D) Left fundus photograph demonstrates grade 2 papilledema.

A 23-year-old woman, with a history of cerebral venous sinus thrombosis (CVST) on warfarin, presented with acute septic hemarthrosis, requiring surgery. A cerebrovascular consultation was placed for anticoagulation recommendations. Brain magnetic resonance venography revealed a hypoplastic right transverse sinus (figure). Anticoagulation was discontinued. Given her history of headache and papilledema, acetazolamide was started due to clinical suspicion of idiopathic intracranial hypertension (IIH).

Unilateral hypoplasia/aplasia of the transverse sinus is a normal variant observed in 20\%-39\% of healthy people and can mimic CVST. ${ }^{1}$ Transverse sinus stenosis in IIH can also mimic CVST. ${ }^{2}$ Misdiagnosing these entities as CVST can lead to significant complications.

\section{Author contributions}

Study concept and design: Dr. Dawit, D.M. Das, Dr. Acierno, Dr. O’Carroll. Acquisition, analysis, or interpretation of images: Dr. Dawit, Dr. Acierno, Dr. O'Carroll. Drafting of the manuscript: Dr. Dawit, D.M. Das, Dr. Acierno, Dr. O’Carroll. Study supervision: Dr. Acierno,

\section{MORE ONLINE}

$\rightarrow$ Teaching slides

links.lww.com/WNL/

A862

From the Department of Neurology (S.D., C.B.O.), Division of Neuro-Ophthalmology, Department of Ophthalmology (M.D.A.), and Mayo Clinic School of Medicine (D.M.D.), Mayo Clinic, Scottsdale, AZ.

Go to Neurology.org/N for full disclosures. Funding information and disclosures deemed relevant by the authors, if any, are provided at the end of the article. 
Dr. O'Carroll. Critical revision of the manuscript: Dr. Dawit, D.M. Das, Dr. Acierno, Dr. O'Carroll.

\section{Study funding}

No targeted funding reported.

\section{Disclosure}

The authors report no disclosures relevant to the manuscript. Go to Neurology.org/N for full disclosures.

\section{References}

1. Han K, Chao AC, Chang FC, et al. Diagnosis of transverse sinus hypoplasia in magnetic resonance venography: new insights based on magnetic resonance imaging in combined dataset of venous outflow impairment case-control studies: post hoc case-control study. Medicine 2016;95:e2862.

2. Aldossary NM. Value of double-track sign in differentiating primary from thrombosed transverse sinus stenosis in patients presumed to have idiopathic intracranial hypertension. eNeurologicalSci 2018;10:22-25. 


\section{Neurology}

\section{Teaching NeuroImages: Congenital variant misdiagnosed as cerebral venous sinus thrombosis: Clinical pitfall}

Sara Dawit, Devika M. Das, Marie D. Acierno, et al.

Neurology 2019;92;e2064-e2065

DOI 10.1212/WNL.0000000000007372

\section{This information is current as of April 22, 2019}

\section{Updated Information \&} Services

References

Subspecialty Collections

Permissions \& Licensing

Reprints including high resolution figures, can be found at: http://n.neurology.org/content/92/17/e2064.full

This article cites 2 articles, 0 of which you can access for free at: http://n.neurology.org/content/92/17/e2064.full\#ref-list-1

This article, along with others on similar topics, appears in the following collection(s):

\section{All Cerebrovascular disease/Stroke}

http://n.neurology.org/cgi/collection/all_cerebrovascular_disease_strok e

All Clinical Neurology

http://n.neurology.org/cgi/collection/all_clinical_neurology

All Neuro-ophthalmology

http://n.neurology.org/cgi/collection/all_neuroophthalmology

Idiopathic intracranial hypertension

http://n.neurology.org/cgi/collection/idiopathic_intracranial_hypertensi on

MRI

http://n.neurology.org/cgi/collection/mri

Information about reproducing this article in parts (figures,tables) or in its entirety can be found online at:

http://www.neurology.org/about/about_the_journal\#permissions

Information about ordering reprints can be found online:

http://n.neurology.org/subscribers/advertise

Neurology ${ }^{\circledR}$ is the official journal of the American Academy of Neurology. Published continuously since 1951, it is now a weekly with 48 issues per year. Copyright @ 2019 American Academy of Neurology. All rights reserved. Print ISSN: 0028-3878. Online ISSN: 1526-632X.

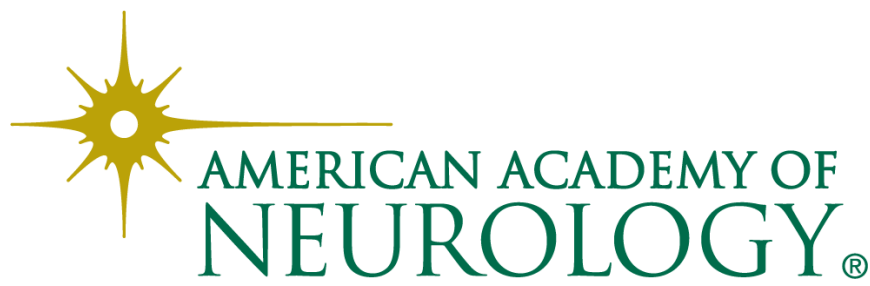

